\title{
Characteristics of phytoplankton distribution for assessment of water quality in the Zhalong Wetland, China
}

\author{
N. N. Zhang ${ }^{1} \cdot$ S. Y. Zang ${ }^{1}$
}

Received: 31 August 2013/Revised: 16 October 2013/Accepted: 14 March 2015/Published online: 9 April 2015

(C) Islamic Azad University (IAU) 2015

\begin{abstract}
Phytoplankton community structures of water environmental were monitored from July to August 2010 in Zhalong Wetland in northeast China. Phytoplankton community was obtained from samples taken from 341 stations with different environmental conditions. Physicochemical parameters (chemical oxygen demand, the total nitrogen, the total phosphorus, chlorophyll $a(\mathrm{Chl}-\mathrm{a})$ ) were measured simultaneously for comparison with phytoplankton samples. A total of 410 phytoplankton taxa belonging to 7 phyla, 9 classes, 20 orders, 29 families, 79 genera were obtained. The mean value of trophic state index (TSI) was 49.87 and ranged from 34.89 to 69.12 . The dominant species in the study area included Anabaena azotica, Selenastrum minutum, Chlorella vulgaris, Trachelomonas volvocina, Navicula radiosa, and indicator species suggesting that most of the Zhalong Wetland is mesotrophic. The TSI, phytoplankton density, Shannon-Wiener index, Margalef index also indicated that the water quality was a mesotrophic state in Zhalong Wetland.
\end{abstract}

Keywords Phytoplankton community · Physicochemical parameters · Phytoplankton diversity - Water quality . Zhalong Wetland

S. Y. Zang

zsy6311@163.com

1 Key Laboratory of Remote Sensing Monitoring of Geographic Environment, College of Heilongjiang Province, Harbin Normal University, No. 1 South Shida Road, Limin Economic Development Zone, Harbin 150025, Heilongjiang, People's Republic of China

\section{Introduction}

Wetland is such a unique ecological system that forms an important protective barrier for pollutant control and protection between water and land. It plays an essential role in keeping the natural ecological balance, improving the condition of natural resources, and providing ecosystem services. Compared with other ecological systems, wetland has many functions, such as special ecological niche, critical water resource and raw material provision, environment purification, and bio-diversity conservation ( $\mathrm{Lu} \mathrm{1990;}$ Costanza et al. 1997).

Based on the matrix-microorganism-plant, the wetland can utilize its own composite ecological system coordination interior physical, chemical, and biological processes, it can remove the suspended solids, organisms, $\mathrm{N}, \mathrm{P}$, and heavy metals in the wastewater to purify the wastewater efficiently by means of filtration, absorption, precipitation, ion exchange, microbial assimilation and decomposition, and plant uptake (Edward 1997).

Despite so many functions of wetland, the rate of eutrophication in the natural water surface of China has been more than $30 \%$ (Zhang and Yang 2001). Eutrophication generally refers to increased aquatic productivity due to increased availability of nutrients, with an array of cascading consequences within the system (Vollenweider 1989; Vetrimurugan et al. 2013; Tanik et al. 2013; Parmar and Bhardwai 2013; Shao et al. 2013; Chow et al. 2012; Rizvi et al. 2012). Nutrient loading to freshwater and coastal ecosystems can be a result of fossil fuel combustion, human waste disposal, urbanization, and agricultural activity. Human activities have roughly doubled the annual global rates of nitrogen fixation, whereas the phosphorus accumulation within terrestrial soils and aquatic sediments has increased at least by $75 \%$ over pre-industrial levels 
(Bennett et al. 2001; Vitousek et al. 1997). The elevated nutrient loading to rivers and coastal waters leads to harmful algal blooms and regional hypoxia (Diaz and Rosenberg 2008).

Phytoplankton, as primary producers in hydrosphere ecosystem, is characterized by strong vitality, rapid reproduction and sensitive reaction to the environment changes (Liu et al. 2003). Furthermore, it is also food sources for underwater organisms, and its distribution has a very close relationship with water environment. Its species composition and community structure are one of the most important factors reflecting water quality (Comin et al. 1990). The use of algae as bioindicator has been discussed for most 100 years, and the first indicator system was published by Kolkwiz and Marsson (1908). Algae are typically aquatic organisms able to record all the environmental evens that occur in a water body. The sensitivity of algae to environmental condition and changes is commonly used in different ecological and paleoecological investigations (Stoermer and Smol 1999; Ács et al. 2003).

The objectives of the current study were to: (1) measure the physiochemical parameters of water quality in the Zhalong Wetland, (2) identify the phytoplankton species, community structure and phytoplankton biodiversity, and (3) assessment the water quality by analysis the physiochemical parameters, TSI, phytoplankton dominant species and Shannon-Wiener index, Margalef index, and phytoplankton density in Zhalong Wetland.

\section{Materials and methods}

\section{Study area}

The Zhalong Wetland is located on Songnen Plain of the Songhua River Basin, lower reaches of Wuyu'er River, in the west Heilongjiang Province, China. It is approximately $2,100 \mathrm{~km}^{2}$ located within latitudes $46^{\circ} 52^{\prime} \mathrm{N}$ to $47^{\circ} 32^{\prime} \mathrm{N}$ and longitudes $123^{\circ} 47^{\prime} \mathrm{E}$ to $124^{\circ} 37^{\prime} \mathrm{E}$ and is in a temperate continental monsoon climate zone. The average altitude is approximate $144 \mathrm{~m}$, the mean annual temperature is $3.9{ }^{\circ} \mathrm{C}$, and the mean annual precipitation is approximate $402.7 \mathrm{~mm}$. Marshes, lakes, and rice paddy fields are the main habitat types in the wetland, and reed marsh covers $80-90 \%$ of the area.

In 1992, the Zhalong Wetland was listed as a Wetland of International Importance. In order to better manage the Zhalong Wetland in 2001, it was divided into the core zone, the buffer zone, and the experimental zone. In accordance with the variation of the physiochemical parameters in Zhalong Wetland, 341 sampling stations using GPS were divided into three study areas (Fig. 1): the core zone (included mainly core zone); the buffer zone (included the buffer zone and experimental zone); and the sewage zone (included the outlet of sewage in Lindian Town).

\section{Phytoplankton qualitative and quantitative samples}

From July to August 2010, 341 phytoplankton samples were collected in Zhalong Wetland. These samples were collected twice from the same sites. The collection was conducted from the surface water to a depth of $0.5-1.0 \mathrm{~m}$ using plankton net $(26 \mu \mathrm{m}$ mesh size $)$ and then preserved in $4 \%$ formaldehyde. Collected samples were transported to the Geography Laboratory at Harbin Normal University, Harbin, China, and transferred to $1000 \mathrm{~mL}$ bottles. After fixing with $10 \mathrm{~mL}$ Lugol's iodine solution and sedimentation for $48 \mathrm{~h}$, the phytoplankton samples were concentrated to $30 \mathrm{~mL}$ and mixed, and $0.1 \mathrm{~mL}$ concentrated samples were counted using an Olympus optical microscope at $400 \times$. Phytoplankton was identified to genus or species, and at least 300 phytoplankton cells were counted per sample. Classification and identification of phytoplankton species were based on Krammer and Lange-Bertalot (1999-2000) and Krammer (2002).

\section{Physical and chemical analysis}

During each sample collection, water temperature, $\mathrm{pH}$, and Chl-a were measured using a hand-held Manta 2 (Eureka, USA), and a water sample was collected simultaneously with each phytoplankton sample. The water samples were stored in $500 \mathrm{~mL}$ bottles, kept in a cooler $\left(4^{\circ} \mathrm{C}\right)$ and transferred to laboratory for analyzed.

TP was measured following the Molybdate Spectrophotometric Method (SEPA 2002), TN was measured following the Alkaline Potassium Persulfate Digestion-UV Spectrophotometric Method (SEPA 2002), and Chemical Oxygen Demand $\left(\mathrm{COD}_{\mathrm{Mn}}\right)$ was measured following the Sodium Oxalate Method (SEPA 2002).

\section{Biological diversity index}

Biological diversity index was evaluated using the Shannon-Wiener diversity index and the Margalef index ( $\mathrm{Li}$ and Yu 2003).

Shannon-Wiener index:

$H=-\sum_{i=1}^{s}\left(\frac{n_{i}}{N} \log _{2} \frac{n_{i}}{N}\right)$

Margalef index:

$D=\frac{S-1}{\log _{2} N}$ 


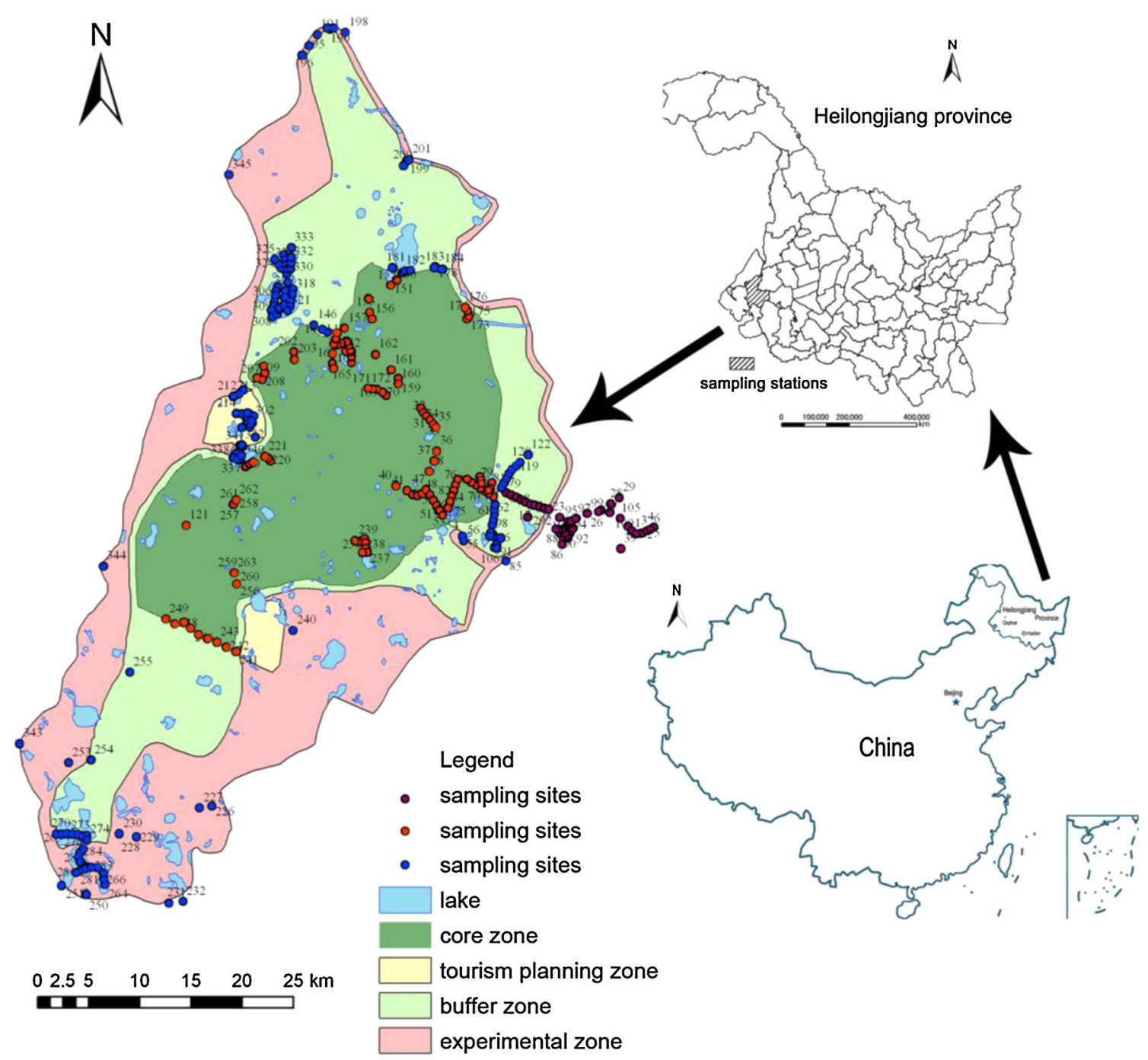

Fig. 1 The distribution of sampling sites in this study in Zhalong Wetland, Heilongjiang Province, China, 2010

where $N$ is the total number of all species in the sample; $\mathrm{S}$ is the total species in the sample; $n_{\mathrm{i}}$ is the total individual numbers in species $i$.

\section{Comprehensive trophic state index}

The comprehensive trophic state index (TSI) was chosen to assess the trophic state of the Zhalong Wetland (Wang et al. 2002), the equations for TSI are as follows:

$$
\begin{aligned}
& \operatorname{TSI}(\text { Chla })=10(2.5+1.086 \ln \text { Chla }) \\
& \operatorname{TSI}(\mathrm{TP})=10(9.436+1.624 \ln \mathrm{TP}) \\
& \operatorname{TSI}(\mathrm{TN})=10(5.453+1.694 \ln \mathrm{TN}) \\
& \operatorname{TSI}\left(\mathrm{COD}_{\mathrm{Mn}}\right)=10\left(0.109+2.66 \ln \mathrm{COD}_{\mathrm{Mn}}\right)
\end{aligned}
$$

where Chl-a is surface algal chlorophyll a $\left(\mu \mathrm{g} \mathrm{L}^{-1}\right)$; TP is the total phosphorus $\left(\mathrm{mg} \mathrm{L}^{-1}\right)$; $\mathrm{TN}$ is the total nitrogen $\left(\mathrm{mg} \mathrm{L}^{-1}\right)$; $\mathrm{COD}_{\mathrm{Mn}}$ is the chemical oxygen demand $\left(\mathrm{mg} \mathrm{L}^{-1}\right)$.

\section{Statistical analysis}

Statistical analyses were performed using Excel for Windows 11.0 software. Spatial distribution mapping of phytoplankton density, Shannon index, and Margalef index using ordinary Kriging was performed with the ArcGIS 9.3, commercial geographic information system software developed by ESRI Co, Redlands, USA.

\section{Results and discussion}

\section{Environmental parameters and comprehensive trophic state index}

Mean concentrations (ranges) of TN, TP, Chl $-a$, and $\mathrm{COD}_{\mathrm{Mn}}$ were $0.26 \mathrm{mg} \mathrm{L}^{-1} \quad(0.05-1.44) \mathrm{mg} \mathrm{L}^{-1}, \quad 0.13 \mathrm{mg} \mathrm{L}^{-1}$ (0.02-0.48) $\mathrm{mg} \mathrm{L}^{-1}, 9.79 \mu \mathrm{g} \mathrm{L}^{-1}(1.13-52.46) \mu \mathrm{g} \mathrm{L}^{-1}$, and $13.1 \mathrm{mg} \mathrm{L}^{-1}$ (3.83-29.25) $\mathrm{mg} \mathrm{L}^{-1}$, respectively, in Zhalong 
Wetland (Fig. 2). There were differences in TN, TP, Chl- $a$, and $\mathrm{COD}_{\mathrm{Mn}}$ concentrations among the three study area. In the core zone, mean concentrations of Chl- $a, \mathrm{TN}, \mathrm{TP}$, and $\mathrm{COD}_{\mathrm{Mn}}$ were $7.41 \mu \mathrm{g} \mathrm{L}^{-1}, 0.21,0.08$ and $11.20 \mathrm{mg} \mathrm{L}^{-1}$, respectively; in the buffer zone, mean concentrations of Chl$a$, TN, TP, and $\mathrm{COD}_{\mathrm{Mn}}$ were $9.44 \mu \mathrm{g} \mathrm{L}^{-1}, 0.21,0.1$ and $13.32 \mathrm{mg} \mathrm{L}^{-1}$, respectively; in the sewage zone, mean concentrations of Chl- $a$, TN, TP, and $\mathrm{COD}_{\mathrm{Mn}}$ were $15.7 \mu \mathrm{g} \mathrm{L}^{-1}$, $0.46,0.3$ and $17.5 \mathrm{mg} \mathrm{L}^{-1}$, respectively.

The mean value of TSI for the Zhalong Wetland was 49.87 and ranged from 34.89 to 69.12 . The minimum value of TSI (TP), TSI (TN), TSI (COD ${ }_{\mathrm{Mn}}$ ), and TSI (Chl-a) was $28.38,3.8,36.85$, and 26.33, respectively. The maximum value of TSI (TP), TSI (TN), TSI (COD ${ }_{M n}$ ), and TSI (Chla) was $82.44,60.68,90.92$, and 48.12, respectively. The mean value of TSI (TP), TSI (TN), TSI (COD $\mathrm{Mn})$, and TSI (Chl-a) was 56.03, 30.86, 67.47, and 48.12, respectively, in Zhalong Wetland. In the core zone, mean value of TSI

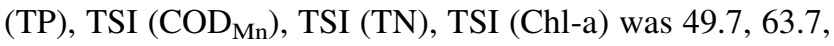
26.9, 45.2, respectively; in the buffer zone, mean value of TSI (TP), TSI (COD ${ }_{\mathrm{Mn}}$ ), TSI (TN), TSI (Chl-a) was 53.8, $68.6,26.2$, 47.1, respectively; in the sewage zone, mean value of TSI (TP), TSI (COD $\left.{ }_{\mathrm{Mn}}\right)$, TSI (TN), TSI (Chl-a) was 73.6, 76.7, 39.3, 50.4, respectively (Fig. 3).

In the current study, the mean concentrations of the physiochemical parameters (Chl-a, TP, TN, COD $\mathrm{Mn}$ ) and TSI were different among the three regions studied in Zhalong Wetland. From the core zone to the sewage zone, the concentrations of physiochemical parameters increased progressively. In the core zone, the water quality was relatively pristine. The broad rich mass of wetland plants in the core area, especially reeds, can be effective in purify water quality; the physiochemical parameters in this zone were relatively low (mean concentrations of Chl- $a$, TN, TP, and $\mathrm{COD}_{\mathrm{Mn}}$ were $7.41 \mu \mathrm{g} \mathrm{L}^{-1}, \quad 0.21,0.08$ and $11.20 \mathrm{mg} \mathrm{L}^{-1}$, respectively), and the TSI (mean value of TSI was 46.4) indicates mesotrophic conditions.

In the buffer zone, water quality has deteriorated. Rubbish, feces, chemical fertilizers, and pesticides, which flow into this region through rainfall and irrigation, have been increasing (Zhou et al. 2007). In addition, with development of the upstream town, pollutant load have been increasing, amounts to 20.459 million tons of industrial sewage and 9.68 million tons of domestic sewage (Wang and Zhang 2006; Zhou et al. 2007). However, the physiochemical parameters were relatively high (mean concentrations of Chl- $a$, TN, TP, and $\mathrm{COD}_{\mathrm{Mn}}$ were $9.44 \mu \mathrm{g} \mathrm{L}^{-1}$, $0.21,0.1$ and $13.32 \mathrm{mg} \mathrm{L}^{-1}$, respectively), and the TSI (mean value of TSI was 49) indicated that the water quality was mesotrophic, but very close to eutrophic.

In the sewage zone, TSI (mean value of TSI was 60) indicates that the water quality is eutrophic. Industrial and agricultural sewage $\left(190 \mathrm{~m}^{3} \mathrm{day}^{-1}\right)$ discharged directly into the wetland from the town of Lindian (Guo et al. 2003), which gives rise to a serious nutrient gradient effecting water quality. Physical-chemical parameters at the
Fig. 2 Spatial distribution of the environmental parameters at Zhalong Wetland Heilongjiang Province, China, 2010. Where Chl-a is surface algal chlorophyll a $\left(\mu \mathrm{g} \mathrm{L}^{-1}\right)$, TP is the total phosphorus $\left(\mathrm{mg} \mathrm{L}^{-1}\right)$, $\mathrm{TN}$ is the total nitrogen $\left(\mathrm{mg} \mathrm{L}^{-1}\right), \mathrm{COD}_{\mathrm{Mn}}$ is the chemical oxygen demand $\left(\mathrm{mg} \mathrm{L}^{-1}\right), \mathrm{I}$ is the core zone, II is the buffer zone, III is the sewage zone

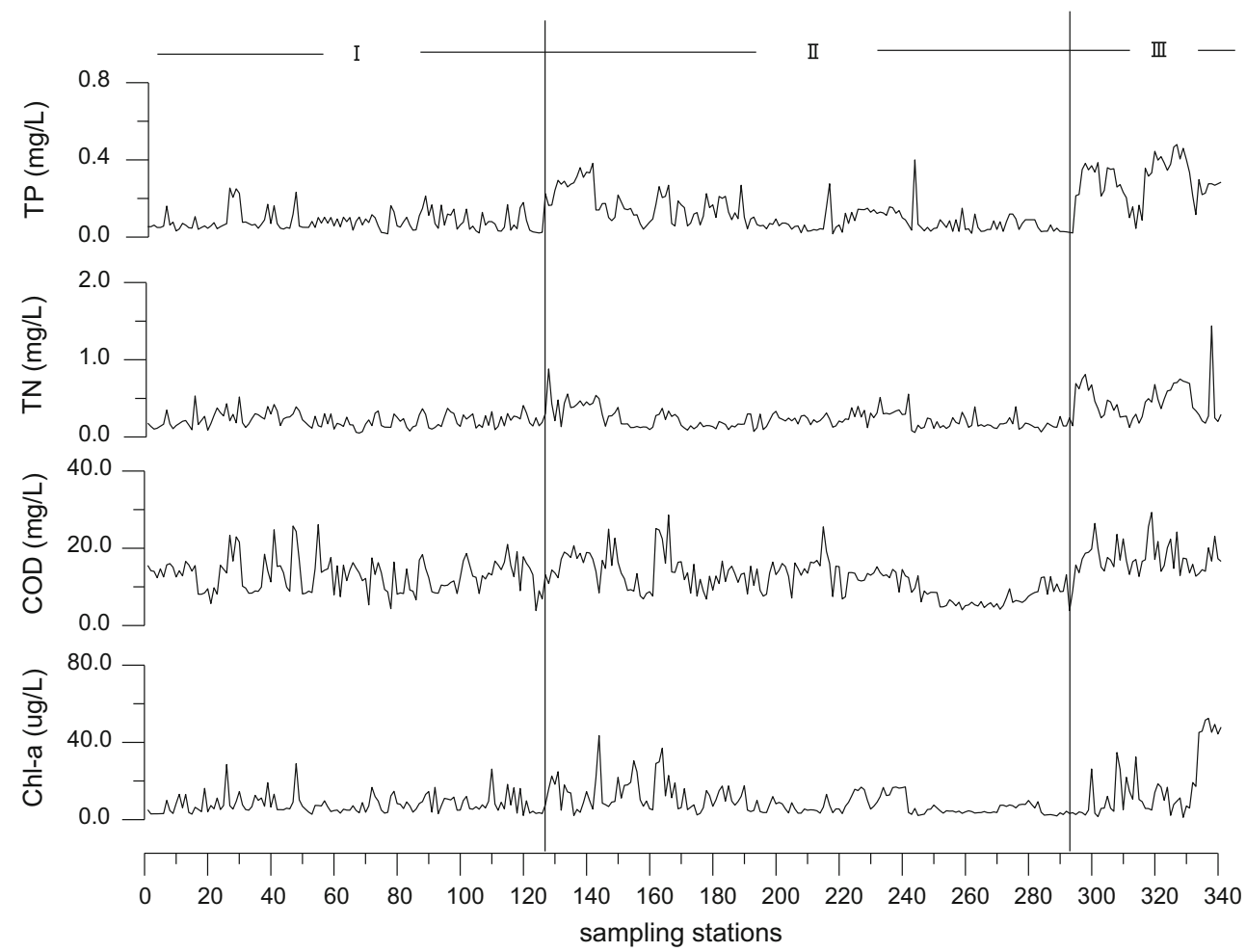




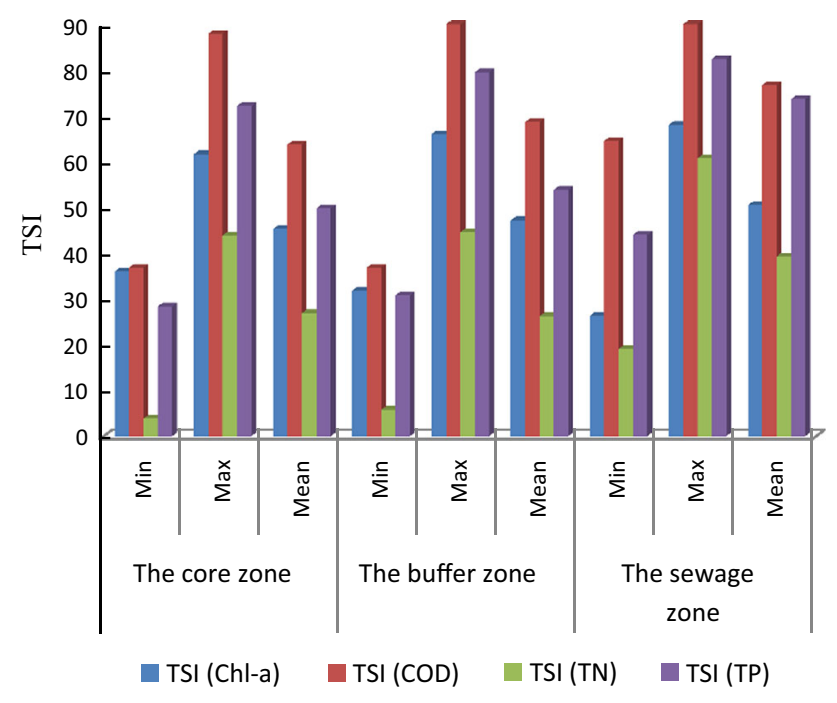

Fig. 3 The comprehensive trophic state index in the three study area of Zhalong Wetland, Heilongjiang Province, China, 2010

sewage discharge outlet were high (mean concentrations of $\mathrm{TP}, \mathrm{TN}, \mathrm{COD}_{\mathrm{Mn}}$, Chl-a were $0.33,0.54,18.14 \mathrm{mg} \mathrm{L}^{-1}$ and $22.13 \mu \mathrm{g} \mathrm{L}^{-1}$, respectively) relative to the parameters (mean concentrations of TP, TN, $\mathrm{COD}_{\mathrm{Mn}}$, Chl-a were 0.27 , $0.43,15.9 \mathrm{mg} \mathrm{L}^{-1}$, and $12.13 \mu \mathrm{g} \mathrm{L}^{-1}$, respectively) at the inlet to the Zhalong Wetland (about $12 \mathrm{~km}$ downstream). The water quality changed from eutrophic to mesotrophic state during the distant to the close along the $8 \mathrm{~km}$ flowed into the wetland.

\section{Phytoplankton analysis}

A total of 410 species of algae were identified in samples collected from 341 sites at the Zhalong Wetland (Table 1). The phytoplankton compositions at sampling sites were typical of mesotrophic wetland. The dominant species in the study area included Anabaena azotica (Cyanophyta), Selenastrum minutum (Chlorophyta), Chlorella vulgaris
Table 1 The 410 species of algae were identified in samples collected from 341 sites at the Zhalong Wetland, Heilongjiang Province, China, 2010

\begin{tabular}{lllllll}
\hline$P$ & $C$ & $O$ & $F$ & $G$ & \multicolumn{1}{l}{$S$} & Average density $\left(\right.$ ind $\mathrm{L}^{-1}$ ) \\
\hline Chlorophyta & 2 & 6 & 9 & 36 & 167 & $3.99 \times 10^{6}$ \\
Bacillariophyta & 2 & 6 & 9 & 24 & 137 & $6.01 \times 10^{6}$ \\
Cyanophyta & 1 & 5 & 6 & 11 & 50 & $2.06 \times 10^{6}$ \\
Cryptophyta & 1 & 1 & 1 & 1 & 2 & $0.40 \times 10^{4}$ \\
Dinophyta & 1 & 1 & 2 & 2 & 5 & $0.30 \times 10^{5}$ \\
Chrysophyta & 1 & 1 & 1 & 1 & 1 & $0.20 \times 10^{5}$ \\
Euglenophyta & 1 & 1 & 1 & 4 & 48 & $0.96 \times 10^{6}$ \\
\hline
\end{tabular}

Where $P$ is the phyla, $C$ is the classes, $O$ is the orders, $F$ is the families, $G$ is the genera, $S$ is species

(Chlorophyta), Trachelomonas volvocina (Euglenophyta), Navicula radiosa (Bacillariophyta), Cyclotella meneghiniana (Bacillariophyta), Rhopalodia gibba (Bacillariophyta), Nitzschia sigm (Bacillariophyta), Anabaena cylindrical (Cyanophyta), Spirogyra communis (Chlorophyta), Oscillatoria subbrevis (Cyanophyta), Scenedesmus arcuatus (Chlorophyta) (Table 2).

Plant community composition both affects and is affected by ecosystem structure and function, for example species composition and diversity strongly influence ecosystem processes, such as nutrient cycling, productivity, decomposition rate, and trophic dynamics, particularly if the traits of one or a few species have strong ecosystem effects (Robert 1977). In general, the dominant plant species account for most of these ecosystem effects because they account for most of the biotic pools and fluxes (Hollingsworth et al. 2008). These results (Table 2) are consistent with previously published data that indicate that dominant species composition can serve as indicator species that reflect the condition of the water environment (Huszar and Reynolds 1997, Reynolds 1998, Hall et al. 2004). Although different phytoplankton species were observed in the three study areas, in general, the majority

Table 2 The dominant species and indictors in the three study area of Zhalong Wetland, Heilongjiang Province, China, 2010

\begin{tabular}{|c|c|c|c|}
\hline & The core zone & The buffer zone & The sewage zone \\
\hline $\begin{array}{l}\text { The } \\
\text { dominant } \\
\text { species }\end{array}$ & $\begin{array}{l}\text { Oscillatoria subbrevis, Chlorella } \\
\text { vulgaris, Trachelomonas volvocina, } \\
\text { Rhopalodia gibba, Oscillatoria princes, } \\
\text { Navicula radiosa, Spirogyra communis, } \\
\text { Nitzschia sigm. }\end{array}$ & $\begin{array}{l}\text { Nitzschia sigma, Scenedesmus arcuatus, } \\
\text { Trachelomonas volvocina, Chlorella } \\
\text { vulgaris, Melosira varians, Navicula } \\
\text { radiosa, Spirogyra communis, } \\
\text { Anabaena azotica, Melosira granulata }\end{array}$ & $\begin{array}{l}\text { Selenastrum minutum, Merismopedia } \\
\text { minima, Navicula minima, Cyclotella } \\
\text { meneghiniana, Chlorella vulgaris, } \\
\text { Gomphonema parvulum, Nitzschia } \\
\text { sigma, Anabaena cylindrical }\end{array}$ \\
\hline Indicators & $\begin{array}{l}\text { Closteriopsis longissima, Micractinium } \\
\text { pusillum, Pediastrum boryanum, } \\
\text { Selenastrum gracile, Scenedesmus } \\
\text { guadricauda, Cocconeis placentula }\end{array}$ & $\begin{array}{l}\text { Asterionella formosa, Cyclotella } \\
\text { meneghiniana, Gomphonema sp., } \\
\text { Melosira granulate, Navicula minima, } \\
\text { Nitzschia sigma, Ankistrodesmus } \\
\text { falcatus, Ankistrodesmus angustus, } \\
\text { Oscillatoria princes }\end{array}$ & $\begin{array}{l}\text { Chlorella vulgaris, Chodatella } \\
\text { quadriseta, Kirchneriella lunaris, } \\
\text { Anabaena flos-aquae, Chroococcus } \\
\text { tenax, Merismopedia minima, } \\
\text { Microcystis aeruginosa, Ceratium } \\
\text { hirundinella }\end{array}$ \\
\hline
\end{tabular}


were mesotrophic indicator species suggesting that most of the Zhalong Wetland was mesotrophic.

\section{Phytoplankton density and diversity}

The total average density of the phytoplankton was $13.18 \times 10^{6}$ ind $\mathrm{L}^{-1}$ (Fig. 4). Bacillariophyta was dominant, with an average density of $6.07 \times 10^{6}$ ind $\mathrm{L}^{-1}$, representing $46 \%$ of the total population, followed by Chlorophyta, average density was $4.02 \times 10^{6}$ ind $\mathrm{L}^{-1}$ (30.5\% of total density) and Cyanophyta, average density was $2.08 \times 10^{6}$ ind $\mathrm{L}^{-1}$ (15.7\% of total density). Cryptophyta was least represented with an average density of $0.4 \times 10^{4}$ ind $\mathrm{L}^{-1}$. Among the three study regions, the mean density ranged from $11.1 \times 10^{6}$ ind $\mathrm{L}^{-1}$ (in the core zone) to $16.4 \times 10^{6}$ ind $\mathrm{L}^{-1}$ (in the sewage zone). Green algae and diatoms represented 52 and $32 \%$, and 42 and $34 \%$ of the densities in the core zone and buffer zone, respectively, while the densities of diatoms $(34.3 \%)$ and green algae $(33.9 \%)$ were similar in the sewage zone.

The mean value of Shannon-Wiener Index was 2.24 and ranged from 1.26 to 2.96 in the Zhalong Wetland (Fig. 4), and the indexes were $2.45,2.3$, and 1.98 in the core zone, buffer zone, and sewage zone, respectively. The mean value of Margalef Index was 1.81 and ranged from 0.57 to 3.47 in the Zhalong Wetland (Fig. 4), and the indexes were $2.25,1.89$, and 1.29 in the core zone, buffer zone, and sewage zone, respectively.

The phytoplankton diversity is a used index for water quality assessment based on changes in phytoplankton density and community structure (Kuang et al. 2005, Zhang et al. 2010). When the community structure got simpler, it
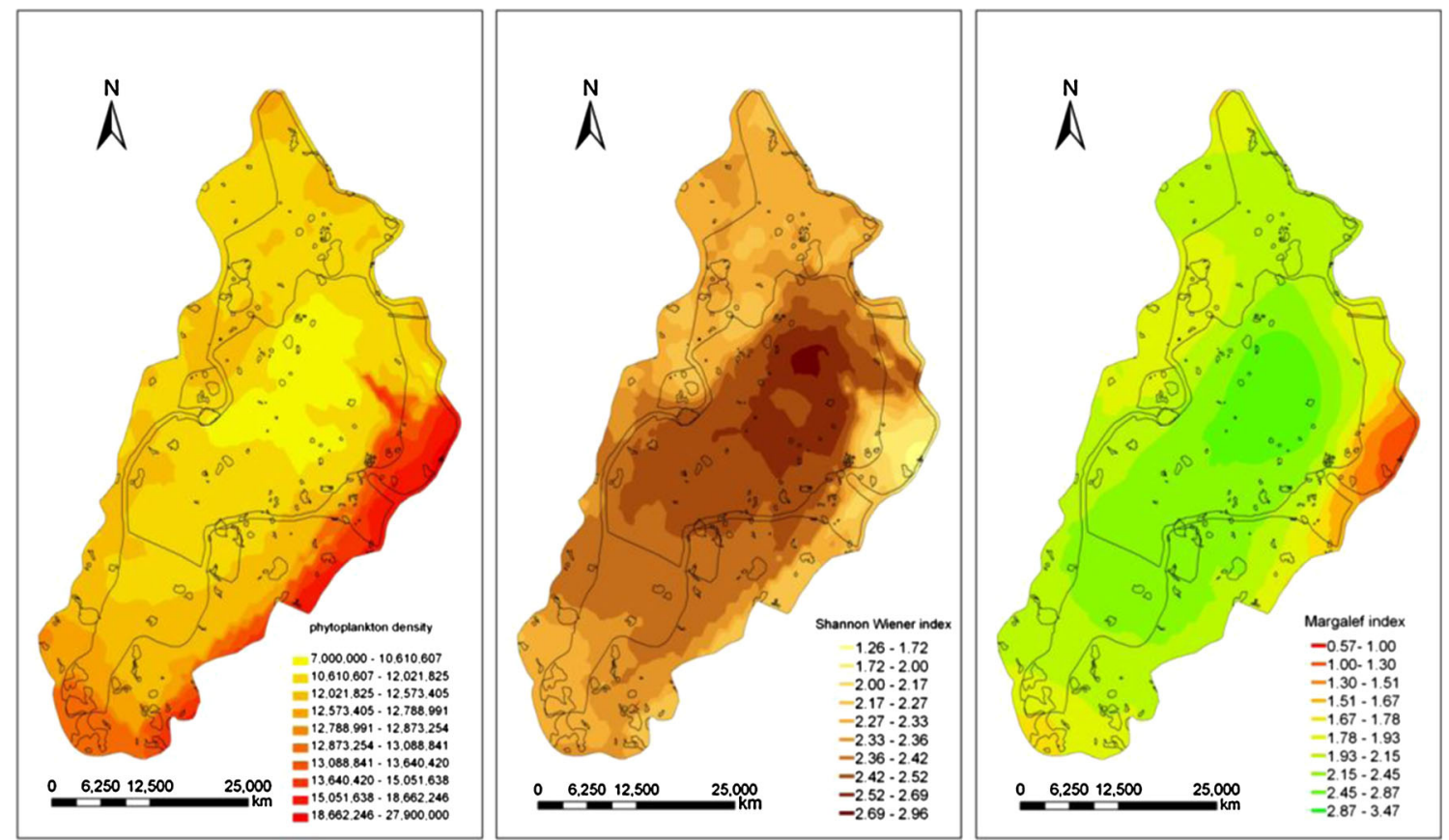

Fig. 4 The distribution of phytoplankton density, Shannon index, and Margalef index in Zhalong Wetland, Heilongjiang Province, China, 2010

Table 3 The water quality evaluation standard with species diversity and comprehensive trophic state index

\begin{tabular}{llllllll}
\hline Evaluation index & \multicolumn{7}{l}{ Evaluation standard } \\
\cline { 2 - 7 } & LO & $O$ & MO & $M$ & ME & $E$ & HE \\
\hline $\mathrm{Chl-a} /\left(\mu \mathrm{g} \mathrm{L}^{-1}\right)$ & $<0.5$ & $<1.0$ & $<5.0$ & $<25.0$ & $<50$ & $<500$ & $\geq 500$ \\
Cell density $/\left(\times 10^{6} \mathrm{~L}^{-1}\right)$ & $\leq 0.5$ & $\leq 1.0$ & $1-9$ & $10-40$ & $41-80$ & $81-99$ & $\geq 100$ \\
Margalef index & 5 (cleanness), $>4$ (oligotrophic), $>3(\beta$-mesotrophic), $<3$ ( $\alpha$-mesotrophic) \\
Shannon index & $>3$ (oligotrophic), $2-3$ ( $\beta$-mesotrophic), $1-2(\alpha$-mesotrophic), 0-1 (eutrophic) \\
TSI & $<30(O), 30-50(M),>50(E), 50-60(\mathrm{LE}), 60-70(\mathrm{ME}),>70(\mathrm{HE})$ \\
\hline
\end{tabular}

Where LO is the light oligotrophic, $O$ is the oligotrophic, MO is the middle oligotrophic, $M$ is the mesotrophic, ME is the middle eutrophic, $E$ is the eutrophic; LE is the light eutrophic, HE is the high eutrophic, TSI is the comprehensive trophic state index 
became more unstable and the water quality was reduced (Guo et al. 2008). In the current study, the ShannonWiener Index (2.25), the Margalef Index (1.82), and the phytoplankton density $\left(13.08 \times 10^{6}\right.$ ind $\left.\mathrm{L}^{-1}\right)$ also indicated a mesotrophic state in the Zhalong Wetland.

Environmental changes and the nutrient status of water quality can be reflected by community structure and composition of phytoplankton (Chattopadhyay et al. 2003), ammonium/ammonia oxidizing prokaryotes (Cao et al. 2011, 2012, 2013; Li et al. 2011) and infauna (Shen et al. 2010). The structures of the dominant species and the variations of indicator species for pollution can reflect environmental quality (Cardinale et al. 2002; Cao et al. 2013). Based on physiochemical parameters, phytoplankton dominant species, phytoplankton diversity index, phytoplankton density, and the comprehensive trophic state index, the water quality of Zhalong Wetland was mesotrophic (Table 3).

Despite the fact that water quality in Zhalong Wetland was in a mesotrophic state, water quality in the sewage zone was eutrophic and in the buffer zone water quality will a trend from mesotrophic to eutrophic. Regulations should be directed toward reducing sewage sources near the town of Lindian that directly impact the water quality of the wetland. This work provided theoretic basis data for spatial grading of service functional values of ecology and wetland ecosystem conservation and utilization in Zhalong Wetland.

\section{Conclusion}

The Zhalong Wetland is located in the west Heilongjiang Province, China. The environmental parameters and phytoplankton were collected from samples taken from 341 stations. A total of 410 phytoplankton taxa belonging to 7 phyla, 29 families, 79 genera were obtained. The mean concentrations of the physiochemical parameters (Chl-a, TP, TN, $\mathrm{COD}_{\mathrm{Mn}}$ ) were different among the three regions studied. From the core zone to the sewage zone, the concentrations of physiochemical parameters increased progressively. The mean value of TSI was 49.87, indicated that the water quality was mesotrophic state. And phytoplankton indicator species, the ShannonWiener Index (2.25), the Margalef Index (1.82), and the phytoplankton density $\left(13.08 \times 10^{6}\right.$ ind $\left.\mathrm{L}^{-1}\right)$ also indicated a mesotrophic state. So managers need effective management approaches to conservation the Zhalong Wetland, it is the internationally important wetland ecosystem.

Acknowledgments This study was financially supported by the key National Natural Science Foundation of China (No.41030743), the
Science and Technology Innovative Programs Foundation of Higher Education of Heilongjiang Province (No.2010td10), the PhD Start-up Fund of Natural Science Foundation of Harbin Normal University of Heilongjiang Province of China (XKB201313). We thank Dr. Richard Halbrook for improving the language.

\section{References}

Ács É, Borsondi AK, Makk J, Molndr P, Mózes A, Rusznyák A, Reskóné MN, Kiss KT (2003) Algological and bacteriological investigations on reed periphyton in Lake Velencei Hungary. Hydrobiologia 506-509:549-557

Bennett EM, Carpenter SR, Caraco NF (2001) Human impact on erodable phosphorus and eutrophication: a global perspective. Bioscience 51:227-234

Cao H, Hong Y, Li M, Gu J-D (2011) Diversity and abundance of ammonia-oxidizing prokaryotes in sediments from the coastal Pearl River Estuary to the South China Sea. Antonie van Leeuwenhoek JMicrobiol 100:545-556

Cao H, Hong Y, Gu J-D (2012) Community shift of ammoniaoxidizing bacteria along ananthropogenic pollution gradient from the Pearl River Delta to the South China Sea. Appl Microbiol Biotechnol 94:247-259

Cao H, Auguet J-C, Gu J-D (2013) Global ecological pattern of ammonia-oxidizing archaea. PLoS One 8:e52853. doi:10.1371/ journal.pone.0052853

Cardinale BJ, Palmer MA, Collins SL (2002) Species diversity enhances ecosystem functioning through interspecific facilitation. Nature 415:426-429

Chattopadhyay J, Sarkar RR, Pal S (2003) Dynamics od nutrient phytoplankton interaction in the presence of viral infection. Bio Syst 68:5-17

Chow MF, Yusop Z, Toriman ME (2012) Modeling runoff quantity and quality in tropical urban catchments using storm water management model. Int J Environ Sci Technol 9:737-748

Comin FA, Menendez M, Lucena JK (1990) Proposal formacrophyte restoration in eutrophic coastal lagoons. Hydrobiologia 200(201):427-436

Costanza R, D'Arge R, Groot R et al (1997) The value of the world's ecosystem services and natural capital. Nature 387:253-260

Diaz RJ, Rosenberg R (2008) Spreading dead zones and consequences for marine ecosystems. Science 321:926-934

Edward BB (1997) Economic valuation of wetlands. Ramsar convention Bureau Gland, Switzerland

Guo YD, Deng W, Pan JH (2003) The characteristics of water eutrophication in Zhalong wetlands and strategy of environmental recovery. Ecol Environ 12(4):393-397

Guo JS, Chen J, Li Z, Fang F, Zhang C, Tian G (2008) Investigation of phytoplankton and assessment of algal diversity on backwater area of Xiaojiang River in Three Gorges Reservoir after its initiate impounding to the water level of $156 \mathrm{~m}$ in spring. Chin J Environ Sci 29(10):2711-2715

Hall SR, Leibold MA, David A, Smith VH (2004) Stoichiometry and planktonic grazer composition over gradients of light, nutrients, and predation risk. Ecology 85:2291-2301

Hollingsworth TN, Schuur EAG, Chapin FS, Walker MD (2008) Plant community composition as a predictor of regional soil carbon storage in Alaskan boreal black spruce ecosystems. Ecosystems 11:629-642

Huszar VLM, Reynolds CS (1997) Phytoplankton periodicity and sequences of dominance in an Amazonian flood-plain lake (Lago, Pará, Brazil): responses to gradual environmental changes. Hydrobiologia 346:169-181 
Kolkwiz R, Marsson M (1908) Ökologie der pflanzlicheSaprobien. Ber Bunsen-Ges Phys Chem 26:505-519

Krammer K (2002) Diatoms of Europe: diatoms of the European inland waters and comparable habitats. Gantner, Ruggell

Krammer K, Lange-Bertalot H (1999-2000) Bacillariophyceae 1-4. Teil. Naviculaceae. In: PascherA (ed) Süsswasserflora von Mitteleuropa. Band 2/1-4. Gustav Fischer Verlag, Heidelberg

Kuang QJ, Ma PM, Hu ZY, Zhou GJ (2005) Study on the evaluation and treatment of lake eutrophication by means of algae biology. J Saf Environ 5(2):87-91

Li GG, Yu ZM (2003) Community structure of rotifer and ecological assessment of water quality in Qiandao Lake. J Lake Sci 15(2):169-178

Li M, Hong YG, Cao HL, Gu JD (2011) Mangrove trees affect the community structure and distribution of anammox bacteria at an anthropogenic-polluted mangrove in the Pearl River Delta reflected by $16 \mathrm{~S}$ rRNA and hydrazine oxidoreductase (HZO) encoding gene analyses. Ecotoxicology 20:1780-1790

Liu DY, Sun J, Zhang LY (2003) Structural characteristics of phytoplankton community during harmful algae bloom in Jiaozhou Bay. Chin J Appl Ecol 14(11):1963-1966

Lu JJ (1990) Wetlands in China. East China Normal University Press, Shanghai

Parmar KS, Bhardwai R (2013) Water quality index and fractal dimension analysis of water parameters. Int $\mathrm{J}$ Environ Sci Technol 10:151-164

Reynolds CS (1998) What factors influence the species composition of phytoplankton in lakes of different trophic status? Hydrobiologia 369(370):11-26

Rizvi SA, Latif M, Ahmad S (2012) Mapping spatial disparity of canal water distribution under irrigated cropping environment using satellite imageries. Int J Environ Sci Technol 9:441-452

Robert E (1977) A trophic state index for lakes. Limnol Oceanogr 22(2):361-369

Shao J, Li R, Lepo JE, Gu JD (2013) Potential for control of cyanobacterial blooms using bioactive substances: problems and prospects. J Environ Manag 125:149-155
Shen P, Zhou H, Gu JD (2010) Patterns of polychaete communities in relation to environmental perturbations in a subtropical wetland of Hong Kong. J Mar Biol Asso UK 90:923-932

State Environmental Protection Administration (SEPA) of China (2002) Monitoring and analysis method of water and wastewater. China Environmental Science Press, Beijing

Stoermer EF, Smol JP (1999) The diatoms: applications for the environmental and earth sciences. Cambridge University Press, Cambridge

Tanik A, Ozalp D, Seker DZ (2013) Practical estimation and distribution of diffuse pollutants arising from a watershed in Turkey. Int J Environ Sci Technol 10:221-230

Vetrimurugan E, Elango L, Raimohan N (2013) Sources of contaminants and groundwater quality in the coastal part of a river delta. Int J Environ Sci Technol 10:473-486

Vitousek PM, Aber JD, Howarth RW, Likens GE, Matson PA, Schindler DW, Schlesinger WH, Tilman GD (1997) Human alteration of the global nitrogen cycle: sources and consequences. Ecol Appl 7:737-750

Vollenweider RA (1989) Global problems of eutrophication and its control. Symp Biol Hung 38:19-41

Wang L, Zhang GX (2006) Responds of Zhalong wetland to Wuyu'er river hydrological characters. J Arid Land Resour Environ 20(6):94-98

Wang MC, Liu XQ, Zhang JH (2002) Evaluate method and classification standard on lake eutrophication. Environ Monit China 18(5):47-49

Zhang W, Yang XS (2001) Eutrophication and controls of water. Bull Biol 36(11):20-22

Zhang JP, Huang XP, Jiang ZJ, Huang DJ, Huang LM (2010) Assessment of the Pearl River Estuary pollution by water comprehensive pollution index and biodiversity index. J Trop 29(1):69-76

Zhou LF, Xu SG, Sun WG (2007) Comprehensive evaluation on water environment quality of Zhalong wetland based on grey clustering method. J Dalian Univ Technol 47(2):240-245 